Dept. of Surgery,

Fac. Vet. Med., Assiut University.

\title{
DANGER OF SOME FOREIGN OBJECTS PENETRATION AND THEIR MIGRATION IN ANIMAL TISSUES
}

(With 2 Tables and 12 Figures)

\begin{abstract}
By
MAGDA M. ALI

(Received at 18/6/2007)

خطر اختراق وانتقال بعض المواد الغريبة الصلبة عبر انسجة جسم الحيوان

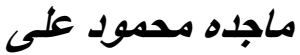

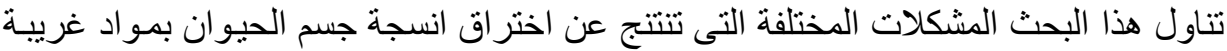

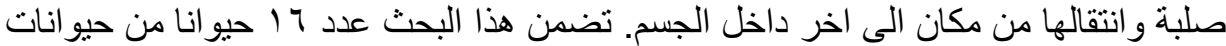

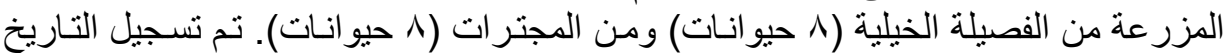

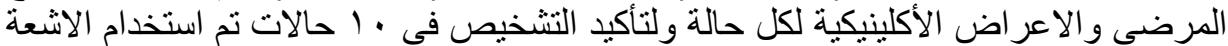

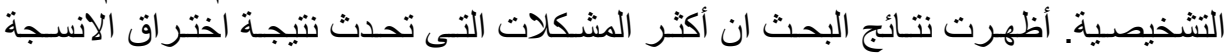

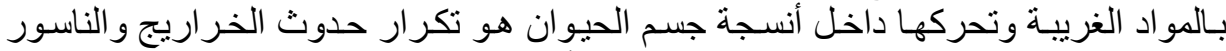

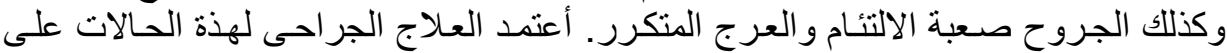

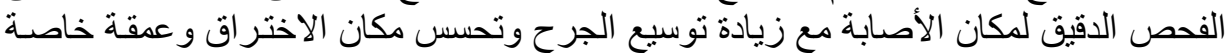

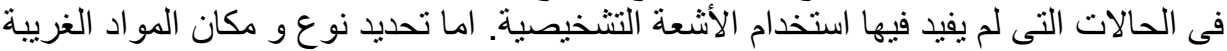

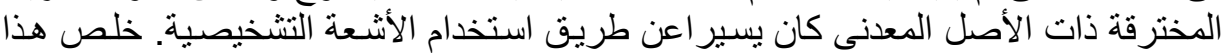

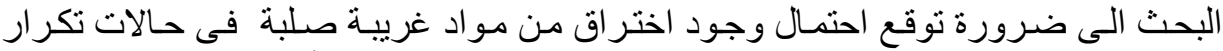

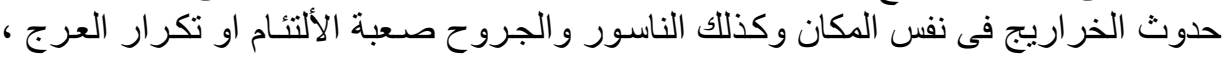

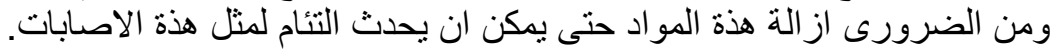

\section{SUMMARY}

This article describes different complications which occur due to injury of body tissues with foreign objects and/or their migration through the animal's body in farm animals. The Study was performed on 16 farm animals of different species (eight equines and eight ruminants). The case history and the clinical signs were recorded for each case; radiography was used to confirm the diagnosis in 10 cases. The most common forms of complications recorded to occur due to the injury with foreign objects and their migration through the body tissues were: 
recurrent abscesses, fistulae, hard to heal wounds and recurrent lameness. Surgical management was based mainly on thorough exploration of the site of lesion with widening and finger palpation of the site of lesion. Determination of the site and type of the foreign object was easy determined with the use of radiographic examination. In conclusion foreign objects should be suspected to be the real cause in any case of recurrent abscesses, fistulae, or hard to heal wounds or in cases of recurrent lameness. Removal of these materials is important to allow complete recovery of the lesion.

Key words: Foreign objects, migration, tissue injury

\section{INTRODUCTION}

Injuries of healthy body tissues with foreign materials are very common in all animal species and human (Hunter and Mihra 2003, Brisson et al. 2004, Staudte et al., 2004). These foreign materials may be inserted into a body cavity, or enlodeged into the body tissues. Splinters, needles, glass, thorns and plant materials are the main causes of vague clinical signs at the time of initial presentation but can progress to cause persistent abscessiation, sinus tract formation and debilitating diseases due to their migration (Staudte et al., 2004).

Foreign objects inserted into the body tissues may cause only minor injury but sometimes they may provide a great deal of amusement as they may be overlooked leading to harm to the patient (Hunter and Mihra 2003). Migration of objects through the body tissues results in many complications which manifested by clinical symptoms that differ according to their nature and type of injury (Chee and Sethi 1999, Calfee and Manning 2002).

The common complications which occur due to injury of body tissues with foreign objects and their migration through the body tissues in farm animals, as well as the methods of their diagnosis and the surgical management of these cases are discussed in this article.

\section{MATERIALS and METHODS}

The present study was carried out on 16 farm animals of different species (seven donkeys, one horse, four cows, one buffalo, two sheep and one goat).

The diagnosis was based mainly on case history, physical examination and in 10 of theses cases which were admitted to the university teaching hospital, Assiut University; diagnostic radiography 
was done to confirm the diagnosis. The other 6 animals were examined in the surrounding field outside the clinic and radiographic examination was not possible.

\section{Anesthesia:}

Surgical management was done under the effect of xylazine** sedation in ruminants in a dose rate of $0.1 \mathrm{mg} / \mathrm{kg}$, I.M. for cattle and buffalo, and $0.05 \mathrm{mg} / \mathrm{kg}$ for sheep and goat. For equines $10 \%$ chloral hydrate narcosis in a dose rate of $6 \mathrm{gm} / 50 \mathrm{~kg}$ BW. I.V. was used. In addition, local infiltration analgesia in the form of field block around the affected area by using $2 \%$ xylocaine $\mathrm{Hcl}$ was used.

\section{Surgical management}

In all examined animals, the wounds, abscesses, and/or the fistulae opening were widened. The depth of these lesions was examined deeply by finger's palpation to detect the presence of foreign materials. Extraction of the foreign object was done by using a long artery forceps (Fig. 1). The soft tissues surrounding the affected area were curetted and the edges were refreshed. The site of lesion was cleaned up and disinfected with $3 \%$ Tincture of iodine. The wound was left opened to heal by second intention and a gauze drain was applied for three days. Systemic antibiotic was applied for all cases for four days.

In one animal suffered from a nail penetration of the deep tissue of the sole. Paring and thinning of the sole using a hoof knife was done deeply through the sole till the head of the nail was found and the nail was extracted. The perforated sole was disinfected using hydrogen peroxide followed by $3 \%$ Tincture of iodine, and then sulphanilamide powder and pressure hoof bandage was applied, which changed every 4 days.

Intestinal fistula on the ventral abdominal wall was diagnosed in two animals; the area around the fistula was prepared for aseptic surgery. The fistula's opening was dissected from the surrounding tissues. The abdominal layers were widened by scissor. A needle was found penetrating the intestinal wall in one animal and in the another one a piece of wire was found attached to the tissues surrounding the fistulas opening. The intestinal wall around the fistula's opening appeared necrosed. After removal of the foreign object, the affected part of the intestine was resected and an end to side anastmosis was applied using No. 0 catgut in a simple interrupted pattern (Fig. 2). The peritoneum, abdominal muscles and the skin were sutured separately by using No. 0 
catgut and No. 1 silk for the skin. The skin stitches were removed 10 days post operation.

\section{RESULTS}

The main case history recorded in the examined cases was the presence of a chronic recurrent affection in the form of: lameness, recurrent suppuration, abscess and intestinal fistula. Several trials for treatment of these lesions were done before but without success. The duration of the affection varied from four days to one year. In 15 of the examined animals, the case history mentioned by the owners was not clear for the veterinarian to identify the possibility of presence of a foreign object as a main cause of the lesion.

Radiographic examination was successfully diagnostic in three cases (a nail penetrating the sole in one donkey, a needle in the lateral thoracic wall in a cow and a wire piece at the level of the pastern joint in a cow). Other foreign objects as thorn, plastic rope and glass could not be diagnosed radiographically. However, increased soft tissue density around the site of the foreign object was seen radiographically in six cases.

The case history, physical examination and the results of radiographic examination of each case are summarized in Table 1.

In the present study no predilection seat in the animal body was recorded for the presence of the foreign objects. The type of foreign objects causing the lesions was varied from one animal to another. These foreign objects and their locations were summarized in Table 2.

Widening of the wound openings, abscess and/or fistula with thorough examination of the depth of the lesion with finger palpation and removal of all necrotic tissues in the affected area allowed easier access to the foreign objects and their extraction in all examined animals. Curetting of the wound surface after extraction of the foreign object, allowed removal of any remnants from the foreign object especially in cases of thorn or plastic rope foreign objects.

In the two cases of the intestinal fistula in sheep, resection of the affected part of the intestine and the application of an end to side anastmosis allowed normal passage of the intestinal contents and the animal was survived without any postoperative complications. Fellow up of the cases recorded no post-treatment complications and healing of the lesions tock place dramatically. 


\section{Table 1: Summarization of case history, physical and radiographic examinations in each animal.}

\begin{tabular}{|c|c|c|c|c|}
\hline Animal & No & Case history & Physical examination & $\begin{array}{l}\text { Radiographic } \\
\text { examination }\end{array}$ \\
\hline Donkey & 1 & $\begin{array}{l}\text { Lameness on the right } \\
\text { forelimb since one month }\end{array}$ & $\begin{array}{l}\text { Old small wound opening at the } \\
\text { level of the carpal joint with pain } \\
\text { on palpation and swelling of the } \\
\text { joint }\end{array}$ & $\begin{array}{l}\text { Increased soft tissue } \\
\text { density around the } \\
\text { joint }\end{array}$ \\
\hline Donkey & 1 & $\begin{array}{l}\text { Left hind limb lameness since } \\
\text { two weeks after injury with a } \\
\text { thorn which was not extracted } \\
\text { completely }\end{array}$ & $\begin{array}{l}\text { The affected area was swollen, } \\
\text { painful on palpation with presence } \\
\text { of a small wound opening }\end{array}$ & \\
\hline Donkey & 4 & $\begin{array}{l}\text { Intermittent lameness in the } \\
\text { fore limb since one month } \\
\text { with swelling at the area of } \\
\text { the digit }\end{array}$ & $\begin{array}{l}\text { The swelling was painful on } \\
\text { palpation, did not cover with hair } \\
\text { and had a small opening }\end{array}$ & $\begin{array}{l}\text { increased soft tissue } \\
\text { density at the area of } \\
\text { the digits }\end{array}$ \\
\hline Donkey & 1 & $\begin{array}{l}\text { lameness without weight } \\
\text { bearing on the right hind limb } \\
\text { since four days }\end{array}$ & $\begin{array}{l}\text { Swelling above the coronet and } \\
\text { Pain on palpation of the hoof with } \\
\text { a hoof tester }\end{array}$ & $\begin{array}{l}\text { A nail penetrating the } \\
\text { sole (Fig.3) }\end{array}$ \\
\hline Horse & 1 & $\begin{array}{l}\text { Recurrent swelling } \\
\text { discharging pus above the } \\
\text { coronet since one year }\end{array}$ & $\begin{array}{l}\text { Suppurative painful swelling } \\
\text { extending deep into the hoof and } \\
\text { bleed easily with manipulation } \\
\text { (Fig. 4) }\end{array}$ & \\
\hline Cow & 1 & $\begin{array}{l}\text { Lameness on the left forelimb } \\
\text { with recurrent abscesses } \\
\text { formation }\end{array}$ & $\begin{array}{l}\text { An old abscess on the lateral aspect } \\
\text { of the upper third of the metacarpal } \\
\text { region, it was painful and hot on } \\
\text { palpation (Fig. 5) }\end{array}$ & $\begin{array}{l}\text { No clear radiographic } \\
\text { changes were } \\
\text { observed }\end{array}$ \\
\hline Cow & 1 & $\begin{array}{l}\text { Swelling discharging pus on } \\
\text { the right mandible wall since } \\
\text { two months (Fig. 6) }\end{array}$ & $\begin{array}{l}\text { Old abscess with thickened capsule } \\
\text { and swelling of the tissues } \\
\text { surrounding, the lesion extends } \\
\text { caudally till the mandibular lymph } \\
\text { node }\end{array}$ & $\begin{array}{l}\text { Increased soft tissue } \\
\text { density in the whole } \\
\text { area around the bone } \\
\text { of the mandible }\end{array}$ \\
\hline Cow & 1 & $\begin{array}{l}\text { Non healed wound on the left } \\
\text { thoracic wall since three } \\
\text { months }\end{array}$ & $\begin{array}{l}\text { Small wound opening on the left } \\
\text { thoracic wall with thickening of the } \\
\text { tissues surrounding it }\end{array}$ & $\begin{array}{l}10 \mathrm{~cm} \text { needle at the } \\
\text { level of the left } \\
\text { thoracic wall (Fig. 7) }\end{array}$ \\
\hline Cow & 1 & $\begin{array}{l}\text { lameness on the right hind } \\
\text { limb with inability to bear } \\
\text { weight and an old wound at } \\
\text { the level of the heel (Fig. 8) }\end{array}$ & $\begin{array}{l}\text { Pain on palpation of the area of the } \\
\text { heel and the interdigital space with } \\
\text { suppurative inflammation, the } \\
\text { lesion extended deeply }\end{array}$ & $\begin{array}{l}\text { Wire piece at the } \\
\text { level of the pastern } \\
\text { (Figs. 9\&10) }\end{array}$ \\
\hline Buffalo & 1 & $\begin{array}{l}\text { Recurrent abscess caudal to } \\
\text { the left elbow joint since two } \\
\text { months }\end{array}$ & $\begin{array}{l}\text { Doughy swelling caudal to elbow } \\
\text { joint with a small opening about } \\
\text { two cm caudal to it (Fig. 11) }\end{array}$ & \\
\hline Sheep & 2 & $\begin{array}{l}\text { Small ventral abdominal } \\
\text { opening discharging injesta }\end{array}$ & $\begin{array}{l}\text { A fistula connecting through the } \\
\text { intestine and the skin passing } \\
\text { injesta (Fig. 12) }\end{array}$ & \\
\hline Goat & 1 & $\begin{array}{l}\text { Recurrent abscess formation } \\
\text { on the ventral abdominal area }\end{array}$ & $\begin{array}{l}\text { Old umbilical abscess with thick } \\
\text { capsule with a small opening } \\
\text { discharging pus }\end{array}$ & \\
\hline Total & 16 & & & 10 \\
\hline
\end{tabular}


Table 2: Types of foreign objects found in each examined animal and the site of it.

\begin{tabular}{|c|c|c|l|}
\hline Animal & No & Type of foreign body & \multicolumn{1}{|c|}{ Site of lesion } \\
\hline Donkey & 1 & Glass piece & Right Carpal joint \\
\hline Donkey & 1 & Thorn & Lower left meta tarsal region \\
\hline Donkey & 4 & Plastic rope & At the level of the digits \\
\hline Donkey & 1 & Nail & Sole of the right hind limb \\
\hline Horse & 1 & Thorn & $\begin{array}{l}\text { above the cornet in the left } \\
\text { forelimb }\end{array}$ \\
\hline Cow & 1 & Needle & Left thoracic wall \\
\hline Cow & 1 & Thorn & Right mandible wall \\
\hline Cow & 1 & Thorn & $\begin{array}{l}\text { Upper third of the Left } \\
\text { metacarpus }\end{array}$ \\
\hline Cow & 1 & Wire piece & The heel of the right hind limb \\
\hline Buffalo & 1 & Needle & Behind the left elbow joint \\
\hline Sheep & 1 & Needle & Ventral abdominal wall \\
\hline Sheep & 1 & Wire piece & Ventral abdominal wall \\
\hline Goat & 1 & Needle & Umbilicus \\
\hline TOTAL & 16 & & \\
\hline
\end{tabular}

\section{LEGENDS OF FIGURES}

Fig. 1: Removal of a thorn impeded into the soft tissue

Fig. 2: The end to side intestinal anastmosis of the intestine in a sheep

Fig. 3: Radiographic examination of the hoof showing a nail impeded into the sole

Fig. 4: Suppurative inflammation at the level of the coronet in the horse (arrow)

Fig. 5: An abscess on the lateral aspect of the left metacarpal region just under the carpal joint in a cow (arrow)

Fig. 6: An old abscess on the right mandibular area in a cow (arrow)

Fig. 7: Radiographic examination showing a long needle a the level the thorax in a cow

Fig. 8: An abscess at the level of the heel of the right hind limb in a cow

Fig. 9\& 10: Radiographic examination showed a wire enlodged at the level of the pastern joint in a cow

Fig. 11: A swelling located just behind the left elbow joint in a buffalo

Fig. 12: An abdominal fistula discharging ingesta in a sheep (arrow) 
Assiut Vet. Med. J. Vol. 53 No. 114 July 2007 
Assiut Vet. Med. J. Vol. 53 No. 114 July 2007 


\section{DISCUSSION}

Foreign objects may be deposited into the body by a traumatic or iatrogenic injury. In the majority of cases the owners are unable to remember or did not know if their animals are injured with foreign objects or not. This condition results in overlooking the foreign object during treatment and recurrence of the lesion is then common. In the present study the main case history reported by the owners was the presence of a chronic recurrent affection in the form of: lameness, suppurative inflammation, abscess intestinal fistula and hard to heal wounds which did not respond to treatment.

Many authors reported that entrance and migration of foreign objects through the body tissues lead to many complications that differ according to the nature of the foreign body and the way of its entrance into the tissues (Chee and Sethi 1999, Calfee and Manning 2002). The most ingested foreign bodies were recorded to migrate from the stomach after its perforation to the diaphragm, causing inflammatory changes in the abdominal and thoracic cavities as well as intestinal perforation (Vasapollo et al., 1997, Hunt et al., 2004 and Koutinas et al., 2004). In the present study migration of the foreign body from the gastrointestinal tract is thought to be the cause of the abscess occurred in three animals (one cow, one buffalo and one goat) and also to be the cause of the intestinal fistula in two sheep.

Some foreign bodies injure the animal tissues resulting in formation of wounds that do not respond to treatment due to the formation of a sinus tract where the foreign body is located (Brennan et al., 2004, Staudte et al., 2004). The same condition was recorded to occur as a result of migration of a bone sequestrum from a fractured bone (Calfee and Manning 2002, Brennan et al., 2004). Hard to heal wound was diagnosed in two of the examined animals in the present study, in one animal the wound formed at the level of the carpal joint as a result of its penetration with a glass piece and on the second animal the wound formed due to penetration of the heal with a wire piece.

Many types of foreign bodies were recorded to cause tissue injury in different animal species and human including chicken bones, wooden skewer, fish bones, grass pieces and metal objects (Chee and Sethi 1999, Armbrust et al., 2003, Hunter and Mihra 2003, Young et al., 2004, Gnudi et al., 2005). The main types of foreign objects found to cause tissue injury in the present study were thorns (four animals), nails 
(one animal), needles (four animals), glass pieces (one animal), wire piece (two animals) and plastic ropes (four animals).

Diagnosis of foreign objects causing tissue injury is sometimes difficult as they may be overlooked and could be harm to the patient (Hunter and Mihra 2003). Radiographic diagnosis of metallic foreign bodies is a helpful diagnostic technique otherwise non-opaque foreign bodies could be diagnosed with the use of other diagnostic tools as Computed tomography and Ultrasound examinations (Fornage et al., 1986, Spouge et al., 1990, Hunt et al., 2004). In the present study radiographic examination was successfully used in diagnosis of 3 cases of the 10 cases examined radiographically. The foreign objects seen on radiographic examination were the radiobaque objects as wire piece, nail and needle. Otherwise radiolucent foreign bodies as thorn, glass pieces and plastic rope with minimal tissues reaction could not be seen radiographically. Similar findings were also recorded by Hunt et al., (2004). However, the results of the present study showed that thorough surgical exploration of the affected area with widening of the affected part with deep exploration and the use of finger palpation is the best method for detection and removal of the foreign object especially on the field where other diagnostic techniques as radiography are not available. These findings sustain the results of Koutinas et al. (2003), Brennan et al. (2004), Hunt et al. (2004) and Giraldo and Redding (2005).

In conclusion, foreign objects should be always suspected to be the main cause in cases suffering from chronic recurrent affection with recurrent suppurative inflammation, recurrent abscess, and intestinal fistula and hard to heal wounds. Removal of these foreign objects is the main way to get complete and correct recovery of such lesions.

\section{REFRENCES}

Armbrust, L.J.; Biller, D.S; Radlinsky, M.G. and Hoskinson, J.J. (2003): Ultrasonographic diagnosis of foreign bodies associated with chronic draining tract and abscesses in dogs. Vet. Radiol. Ultrasound 44(1): 66-70.

Brennan, S.F.; Connery, N.; Tobin, E.; Mooney, C.T. and Jones, B.R. (2004): Gastrocutaneous fistula as a result of migration of a foreign body in a dog, J. Small Anim. Pract. 45(6): 304-306.

Brisson B.A.; Bersenas, A. Eute, S.M. (2004): Ultrasonographic diagnosis of septic arthritis secondary to porcupine quill migration in a dog J. Am. Vet. Med. Assoc. 1,224(9): 1467-1470. 
Calfee, T. and Manning, T.O. (2002): Non healing subcutaneous wounds in the cats and proposed surgical management techniques. Clin. Tech. Small Anim. Pract. 17(4); 162-167

Chee, L.W. and Sethi, D.S. (1999): Diagnostic and therapeutic approach to migrating foreign bodies. Ann. Otol. Rhinol. Laryngol. 108(2): 177-180.

Fornage, B.D.; Schemberg, F. and Sonographic, L. (1986): Diagnosis of foreign bodies of the distal extremities. AJR Am. J. Roentgenol; 147: 567-569.

Giraldo, L. and Redding, W.R. (2005): Radiographic diagnosis: Foreign body in the distal interphalengeal joint, Vet Radiol Ultrasound 46(4): 304-305.

Gnudi, G.; Volta, A.; Bonazzi, M.; Gazzola, M. and Bertoni, G. (2005): Ultrasonographic features of grass awn migration in the dog, Vet. Radiol. Ultrasound 46(5): 423-426.

Hunt, G.B.; Worth, A. and Marchevsky, A. (2004): Migration of wooden skewer foreign bodies from the gastrointestinal tract in eight dogs, J. Small Anim. Pract. 45(7): 362-364

Hunter, T.B. and Mihra, S. (2003): special report on Foreign bodies, Radiographics, 23, 731-757.

Koutinas, C.K.; Papazoglou, L.G.; Saridomichelakis, M.N.; Koutinas A.F. and Patsikas, M.N. (2003): Caudal medistinal abscess due to a grass awn (Hordeum Spp) in cat, J. Feline Med. Surg. 5 (1): 43-46.

Koutinas, K.C.; Papazoglou, L.G.; Saridomichelakis, M.N.; Koutinas, A.F. and Monies, B. (2004): Alimentary tract perforation in cattle caused by tyre wire. Vet. Rec. May 1; 154 (18): 574-575.

Spouge, A.R.; Weisbrod, G.L.; Herman, S.J. and Chamberlain, D.W. (1990): Wooden foreign body in the lung parenchyma. AJR Am. J. Roentgenol; 154: 999-1001.

Staudte, K.L.; Hopper, B.J.; Gibson, N.R. and Read, R.A. (2004): Use of ultrasonography to facilitate surgical removal of non-enteric foreign bodies in 17 dogs, J. Small Anim. Pract. 45(8):395-400.

Vasapollo, L.; Chiarot, M.; Gallinaro, L.; Papaspyropoulos, V.; Montesano, G.; Ciulli, A. and Bezzi, M. (1997): Intestinal perforation caused by a chicken bone: a propos of a clinical case, Ann. Ital. Chir. 68(4): 555-558.

Young, B.; Klopp, L.; Albrecht, M. and Kraft, S. (2004): Imaging diagnosis: Magnetic resonance imaging of a cervical wooden foreign body in a dog, Vet. Radiol. Ultrasound 45(6): 538-541 